\title{
Campylobacter pinnipediorum subsp. caledonicus and $C$. pinnipediorum subsp. pinnipediorum recovered from abscesses in pinnipeds
}

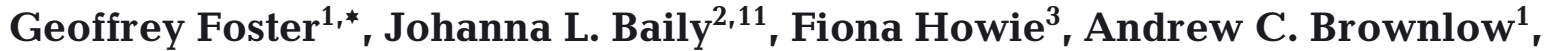 \\ Jaap A. Wagenaar ${ }^{4,5,6}$ Maarten J. Gilbert ${ }^{4,7}$, William G. Miller ${ }^{8}$, Barbara A. Byrne ${ }^{9}$, \\ Kristin A. Clothier ${ }^{9}$, Todd Schmitt ${ }^{10}$, Tony Patterson $^{1}$, Robert J. Reid ${ }^{1}$, Mark P. Dagleish ${ }^{2}$ \\ ${ }^{1}$ SRUC Veterinary Services, An Lochran, 10 Inverness Campus, Inverness IV2 5NA, UK \\ ${ }^{2}$ Moredun Research Institute, Pentlands Science Park, Bush Loan, Penicuik, Midlothian EH26 0PZ, UK \\ ${ }^{3}$ SRUC Veterinary Services, Pentlands Science Park, Bush Loan, Penicuik, Midlothian EH26 0PZ, UK \\ ${ }^{4}$ Department of Infectious Diseases and Immunology, Faculty of Veterinary Medicine, Utrecht University, Yalelaan 1, \\ 3584CL Utrecht, The Netherlands \\ ${ }^{5}$ WHO Collaborating Center for Campylobacter/OIE Reference Laboratory for Campylobacteriosis, Yalelaan 1, \\ 3584CL Utrecht, The Netherlands \\ ${ }^{6}$ Department of Bacteriology and Epidemiology, Wageningen Bioveterinary Research, Houtribweg 39, 8221RA Lelystad, \\ The Netherlands \\ ${ }^{7}$ Reptile, Amphibian and Fish Conservation Netherlands (RAVON), Toernooiveld 1, 6525ED Nijmegen, Netherlands \\ ${ }^{8}$ Produce Safety and Microbiology Research Unit, Agricultural Research Service, United States Department of Agriculture, \\ Albany, CA 94710, USA \\ ${ }^{9}$ Pathology, Microbiology and Immunology, University of California, Davis, CA 95616, USA \\ ${ }^{10}$ SeaWorld San Diego, Veterinary Services, San Diego, CA 92109, USA \\ ${ }^{11}$ Present address: Institute of Aquaculture, University of Stirling, Stirling FK9 4LA, UK
}

\begin{abstract}
Campylobacter pinnipediorum was described recently for isolates recovered from pinnipeds. The novel species was further split into 2 subspecies based on host and geography, with C. pinnipediorum subsp. pinnipediorum recovered from otariid seals in California (USA) and C. pinnipediorum subsp. caledonicus recovered from phocid seals in Scotland. We report details of the infections of 7 pinnipeds from which C. pinnipediorum was isolated: C. pinnipediorum subsp. caledonicus was isolated from 2 harbour seals Phoca vitulina and a single grey seal Halichoerus grypus, and C. pinnipediorum subsp. pinnipediorum was isolated from California sea lions Zalophus californianus. Six of the isolates were recovered from samples collected at post-mortem investigation. In 2 of the Scottish seals and in 3 of the California seals, C. pinnipediorum was the sole bacterial isolate recovered from abscesses present and suggests they may have resulted from conspecific or intraspecific bite wounds.
\end{abstract}

KEY WORDS: Campylobacter pinnipediorum • Bite wounds

\section{INTRODUCTION}

Campylobacter is a bacterial genus that has been associated with asymptomatic carriage and symptomatic infections in humans and other animals (Skirrow
1994). In humans, campylobacteriosis is recognised as the most common cause of bacterial food poisoning in the UK, due mostly to $C$. jejuni and C. coli (Strachan \& Forbes 2010, Tam et al. 2012). The aforementioned species have also been recognised in 
farm and companion animals as well as in wildlife and are established zoonotic pathogens (Sheppard et al. 2009). In addition to the above, further Campylobacter spp. of veterinary importance include $C$. fetus subsp. fetus, which is associated with abortion in sheep and cattle, and reproductive disease in bovids due to C. fetus subsp. venerealis (Skirrow 1994).

Increasing microbiological investigations of wildlife have reported the isolation of Campylobacter spp., including strains infecting marine mammals. In seals inhabiting Scottish coastal waters, these have included C. jejuni, C. coli, C. lari (Baily et al. 2015) and $C$. insulaenigrae (Foster et al. 2004). First reported from 3 seals and a harbour porpoise Phocoena phocoena, the latter has since been reported from seals in other regions of the world (Stoddard et al. 2007, García-Peña et al. 2010, González et al. 2011) but also as a cause of human infections (Chua et al. 2007). Of late, isolates from harbour seals Phoca vitulina in the Netherlands were assigned to the novel species C. blaseri (Gilbert et al. 2018).

Recently, a polyphasic analysis of Campylobacter isolates from pinnipeds resulted in the description of the novel, urease-positive species C. pinnipediorum (Gilbert et al. 2017). This novel species could be subdivided further into 2 subspecies based on phylogenetic analysis and catalase reaction. Notably, the 2 subspecies could also be differentiated by the animal hosts infected and their geographic location: $C$. pinnipediorum subsp. pinnipediorum was recovered from otariid seals in California (USA), and C. pinnipediorum subsp. caledonicus was recovered from phocid seals in Scotland. We report here the details of infections with $C$. pinnipediorum: $C$. pinnipediorum subsp. caledonicus in 2 harbour seals and a grey seal Halichoerus grypus in Scotland and C. pinnpediorum subsp. pinnipediorum in 4 California sea lions Zalophus californianus in California. Six of the isolates were isolated following post-mortem examination.

\section{MATERIALS AND METHODS}

\subsection{Scottish seal cases}

Pinnipeds that stranded in Scotland were reported under the Scottish Marine Animals Strandings Scheme (SMASS) funded by Marine Scotland as part of the UK Government's commitment to a number of international agreements and specifically under European Protected Species licence number 120139. Carcasses were transported to Scotland's Rural College (SRUC) Veterinary Services, Inverness, for a post- mortem examination performed according to a standard protocol (Dierauf 1994). Selected tissues and gross lesions were sampled for microbiological and histopathological diagnoses. Cultures were made on Columbia sheep blood agar (CSBA) (Oxoid) and selectively for Brucella on Farrell's medium, incubated at $37^{\circ} \mathrm{C}$ in air with $5 \%$ added $\mathrm{CO}_{2}$. Selective cultures for Campylobacter and anaerobes incubated in microaerophilic and anaerobic environments were also set up. All plates were examined for growth at frequent intervals up to $14 \mathrm{~d}$.

\subsection{California sea lion cases}

Four California sea lions that live-stranded were rescued and cared for at animal rehabilitation centres in California. Three of the animals were cared for at SeaWorld in California under NMFS Marine Mammal Health and Stranding Response Program Permit 932-1905 and the other at the Pacific Marine Mammal Center in California under NMFS Marine Mammal Health and Stranding Response Program Permit 932-1489. The SeaWorld animals subsequently died and received post-mortem investigations, which included sampling of abscesses. The sea lion at the Pacific Marine Mammal Center in California survived, and abscess exudate was collected for cytology and bacterial culture on $5 \%$ sheep blood agar (Hardy Diagnostics) and incubated at $35^{\circ} \mathrm{C}$ in room air supplemented with $5 \% \mathrm{CO}_{2}$.

\section{RESULTS}

\subsection{Scottish cases}

\section{Case S1}

A juvenile male harbour seal was found live-stranded at Lossiemouth in the Moray Firth $\left(57^{\circ} 66^{\prime} 13.9^{\prime \prime} \mathrm{N}\right.$, $003^{\circ} 61^{\prime} 63.89^{\prime \prime} \mathrm{W}$ ) on 28 October 2000 . There was a large poorly circumscribed sub-blubber abscess above the left shoulder, which contained dark red/brown pus. The left pre-scapular lymph node was markedly enlarged. The seal was also suffering from severe pneumonia and was euthanased on welfare grounds. Large numbers of Campylobacter-like bacteria were the only organisms observed in a Gram-stained smear from the abscess contents, but they were not seen in tissue smears from lung, liver, spleen, kidney or brain. A pure growth of $C$. pinnipediorum subsp. caledonicus (+) was recovered from the abscess on CSBA 
after $10 \mathrm{~d}$ of microaerophilic incubation at $37^{\circ} \mathrm{C}$ and after $14 \mathrm{~d}$ in a capnophilic atmosphere at the same temperature. Microaerophilic cultures from brain, spleen and lung were negative and cultures using Campylobacter-selective media (charcoal cefoperazone deoxycholate agar [CCDA] and Blaser-Wang) were negative for these 3 tissues and the abscess. Additionally, E. coli was recovered from lung (+++), spleen (++), mesenteric lymph node $(++)$, kidney $(+)$, liver (few) and in mixed growth from blood and intestine. Selective culture for Brucella spp. was negative for all tissues. Histological examination of the lung confirmed the presence of parasitic and suppurative bronchointerstitial pneumonia. Larvae were present in the airways with an associated eosinophilic and lymphocytic inflammatory response, and suppurative infiltrates were associated with small numbers of adult worms in alveoli. The section of liver examined was diffusely congested and contained a focus of necrosis and suppurative inflammation. The thymus was depleted. The spleen was congested with evidence of extramedullary haematopoiesis and the kidney was congested.

Histological examination of the brain showed a severe suppurative meningo-encephalitis, as denoted by the presence of large numbers of neutrophils, and protein-rich oedema around blood vessels in the meninges and in the neuropil along with necrosis in the grey matter of the cerebral cortex and white matter of the internal capsule. These lesions are indicative of a bacterial aetiology, possibly with the production of bacterial toxins.

\section{Case S2}

A 3-4 wk old female grey seal pup was found dead at Tyninghame Beach, East Lothian (56 02' $49.53^{\prime \prime} \mathrm{N}$, $002^{\circ} 59^{\prime} 84.13^{\prime \prime} \mathrm{W}$ ) on 9 December 2010. A profuse growth of $C$. pinnipediorum subsp. caledonicus appeared initially as tiny colonies, which were possibly satellitic around other organisms as a mixed growth on chocolate agar incubated at $37^{\circ} \mathrm{C}$ in air plus $5 \% \mathrm{CO}_{2}$ from a lung abscess. Other bacteria isolated were Streptococcus agalactiae, Arcanobacterium phocae and a moderate growth of Salmonella enterica serovar Bovismorbificans. In addition, a profuse growth of an unidentified Fusobacterium sp. was recovered from anaerobic cultures. Interestingly, culture of non-abscessed lung tissue produced all of the aforementioned organisms except Campylobacter. The only other tissues cultured were liver and kidney, which had profuse and moderate growths, respectively, of Salmonella Bovismorbificans, a serovar encountered in grey seals in Scottish waters (Baily et al. 2016). Selective culture for Brucella was negative for all tissues.

\section{Case S3}

A juvenile female harbour seal was found dead at Findhorn in the Moray Firth $\left(57^{\circ} 66^{\prime} 13.9^{\prime \prime} \mathrm{N}\right.$, $003^{\circ} 61^{\prime} 63.89^{\prime \prime}$ W) on 27 November 2011. There was a large abscess within the axillary lymph node under the right scapula, which was confirmed histologically, but no overt evidence of a bite wound. A profuse pure growth of $C$. pinnipediorum subsp. caledonicus was recovered from the abscess in anaerobic culture. The only other bacterial isolate was B. pinnipedialis recovered as single colonies from lung, spleen and mesenteric lymph node and as a moderate growth alongside a sparse mixed growth of other organisms from the small intestine. No growth was obtained from the liver, kidney or brain. Campylobacter cultures of small intestine on Skirrow's agar were negative. Additional histopathology findings included mild drainage reactions in a distant lymph node and the spleen; mildly reactive hepatic sinusoids and mild broncho-interstitial pneumonia associated with adult parasites with gross morphology identical to Parafilaroides sp.

\subsection{California sea lion cases}

\section{Case C1}

An emaciated female California sea lion pup, weighing $12 \mathrm{~kg}$, live-stranded for the second time on 9 March 2013 and died at SeaWorld on 11 March 2013. A $9 \times 5 \times 3 \mathrm{~cm}$ abscess was found on the left pelvic limb surrounded by necrotic muscle and chylous peritoneal effusion containing $30 \mathrm{ml}$ of opaque pink/red fluid. C. pinnipediorum subsp. pinnipediorum was isolated from the effusion along with mixed aerobic and anaerobic bacteria. The primary cause of death was likely sepsis due to the severe focally extensive necrotising myositis, peritonitis and emaciation.

\section{Case C2}

An emaciated juvenile female California sea lion, weighing $11.4 \mathrm{~kg}$, died at SeaWorld on 15 February 2013. Open wounds were found on the lower jaw at 
the corner of the oral cavity and upper lip just behind the vibrissae. There was also a $6.0 \times 3.5 \mathrm{~cm}$ abscess in the neck above the right shoulder joint which was full of opaque pink purulent fluid. Histologic examination of the abscess revealed numerous intact and degenerate neutrophils surrounded by abundant fibroplasia extending into the surrounding muscle and adipose tissues with occasional lymphoid aggregates. C. pinnipediorum subsp. pinnipediorum was isolated from the neck abscess, which was thought to possibly be the result of a bite wound from a conspecific sea lion. The sea lion received injectable antibiotics (ceftiofur), subcutaneous fluids, oral electrolytes and pinniped gruel formula for nutrition. The suspect bite wound abscess was deemed to be the cause of the poor body condition and death.

\section{Case C3}

An emaciated male California sea lion pup, weighing $13 \mathrm{~kg}$, was admitted to SeaWorld on 3 March 2013 and died on 4 March 2013. The hypothermic sea lion was housed inside with a thermal heating pad and treated supportively with subcutaneous fluids $+5 \%$ dextrose, dilute formula and oral electrolytes. Preliminary cell blood count showed a low white blood cell count (5230 cells $\mu^{-1}, 31 \%$ neutrophils, 18\% band neutrophils, $27 \%$ lymphocytes, $16 \%$ monocytes), haematocrit $(46 \%)$, and point-of-care I-stat showed hypoglycaemia (27 $\mathrm{mg} \mathrm{dl}^{-1}$ ) and acidosis ( $\mathrm{pH}$ 7.1). At post-mortem, there was approximately $30 \mathrm{ml}$ of opaque off-white pleural effusion with opaque orange fluid with proteinaceous particles. Both lungs were mottled with dark red regions at the lung periphery. The caudal left lung lobe was enlarged with the edge firm and dark red with clusters of off-white abscesses, from which C. pinnipediorum subsp. pinnipediorum was isolated in small numbers. Histologic examination demonstrated submassive pneumonia with necrosis of terminal bronchioles and alveoli and tissue replacement by degenerate neutrophils, proteinaceous oedema and fibrin. No microorganisms were identified in any sections of the lung. Cause of death was sub-massive necrosis and pneumonia, pleural effusion and septic necrosis in the live.

\section{Case C4}

A California sea lion began treatment at the Pacific Marine Mammal Center on 1 June 2011. Two abscesses were present: 1 on the right dorso- lateral abdomen and 1 in the right thoracic area. The animal was also moderately underweight, with several raised cutaneous nodules on the thoracoabdominal dorsum. Two abscesses were opened, suppurative exudate removed, flushed and instilled with Techni-Care ${ }^{\circledR}$ antiseptic. Cytologic examination of the abscess exudate revealed masses of degenerate and/or necrotic leukocytes, approximately 50:50\% neutrophils:mononuclear cells with occasional scattered erythrocytes; no bacteria were definitively identified. The right dorsolateral abdominal abscess was aspirated, from which C. pinnipediorum subsp. pinnipediorum was the sole isolate. Treatment included flushing with salt and/or tap water, amoxicillin-clavulanic acid (17 $\mathrm{mg} \mathrm{kg}^{-1}$ ) orally twice daily for $6 \mathrm{~d}$. Wound care was terminated $12 \mathrm{~d}$ after admission, and abscesses were noted to be healed 3 wk after admission. The animal was released on 14 August 2011 weighing $44 \mathrm{~kg}$.

\subsection{Characteristics of $C$. pinnipediorum isolates}

On CSBA, the isolates of both subspecies of $C$. pinnipediorum presented as $\alpha$-haemolytic beige, glossy, slightly raised and circular colonies with smooth margins. Growth was observed in microaerophilic and anaerobic environments and at $25^{\circ} \mathrm{C}$ but not in aerobic environments without added $\mathrm{CO}_{2}$, nor at $42^{\circ} \mathrm{C}$. Growth in air with $5 \% \mathrm{CO}_{2}$ varied with strain. All isolates were sensitive to cephalothin $(30 \mu \mathrm{g})$ and nalidixic acid $(30 \mu \mathrm{g})$. Positive reactions were obtained for urea hydrolysis, $\mathrm{H}_{2} \mathrm{~S}$ production from triple sugar iron agar (TSI), nitrate production and oxidase but negative for hydrolysis of hippurate and indoxyl acetate. The aforementioned characteristics are shared between C. pinnipediorum subsp. caledonicus and C. pinnipediorum subsp. pinnipediorum and permitted their distinction from all other validated species of Campylobacter as well as urease-positive C. lari (UPTC) which is not, as yet, a defined taxon (Miller et al. 2014, Gilbert et. al. 2017). Differences in catalase reactions were observed between the Scottish and Californian strains, i.e. catalase-negative for C. pinnipediorum subsp. caledonicus and catalase-positive for C. pinnipediorum subsp. pinnipediorum. Extensive molecular testing, including whole genome sequencing, permitted further distinction between the 2 subspecies of $C$. pinnipediorum. A full description of the characterisation methods and results is provided with the species description of C. pinnipediorum (Gilbert et al. 2017). 


\section{DISCUSSION}

During the years 2000-2011, Campylobacter pinnipediorum subsp. caledonicus was isolated from the abscesses of 2 stranded juvenile harbour seals and a grey seal pup that stranded at different locations around the North Sea coast of Scotland. In each of these cases, a single abscess was the only site from which $C$. pinnipediorum subsp. caledonicus was recovered: 1 in the shoulder region, 1 in a limb and 1 in the lung. C. pinnipediorum subsp. pinnipediorum was recovered from abscesses in 4 California sea lions during 2011 and 2013. In 3 of these abscesses C. pinnipediorum subsp. pinnipediorum was the only organism isolated. It is possible that other cases may have gone undetected, especially if culture under anaerobic or microaerophilic conditions was not performed.

It is interesting to compare these cases with findings from necropsies of 8 harbour porpoises which stranded in Scotland, England, Belgium and the Netherlands, following non-lethal attacks from grey seals (Foster et al. 2019). In all of these cases, Neisseria animaloris was recovered from abscesses in skin and lung, similar to the findings for the seals with $C$. pinnipediorum reported here. Grey seals are known to attack harbour seals (van Neer et al. 2015), harbour porpoises (Leopold et al. 2015) and conspecifics (Brownlow et al. 2016). It is possible that the infections in seals follow a similar course to that of N. animaloris in porpoises, whereby the seals survive an initial assault only to die of complications later, such as abscesses due to $C$. pinnipediorum, either at the site of puncture or following dissemination and abscessation in the lung. Indeed, a recent microbiome study found that $C$. pinnipediorum is part of the grey and harbour seal oral microbiome, being particularly abundant in some grey seals, and was also detected in very low amounts in porpoise lesions as a result of bites from grey seals (Gilbert et al. 2020). Seal lesions were not part of that study; however, the possibility remains that abscesses in seals become infected with $C$. pinnipediorum following traumatic injury from conspecifics or from other pinnipeds. Furthermore, all strains of $C$. pinnipediorum displayed urease activity, which may be related to a gastric niche and also shared 100\% 16S rRNA sequence homology with uncultured bacteria from the gastric microbiota of California sea lions (Bik et al. 2016). C. pinnipediorum subsp. pinnipediorum was also recovered from the rectal swabs of 4 sea lion pups and a yearling.

We suggest that the most likely pathogenesis for the infections presented in this study are abscessation, secondary to bite wounds, likely from pinnipeds. Although bite wounds were not observed, their absence was recorded only for the most recent case and it may be that they went unnoticed in the earlier cases or had resolved. The non-reporting of bite lesions may also reflect slow growth of $C$. pinnipediorum or the effects of other stressors on the pathogenicity of this bacterium. It is possible that smaller puncture wounds may partially heal or be difficult to identify but that $C$. pinnipediorum is inoculated into tissues, is able to thrive and replicate in the low-oxygen environment present in damaged or devitalized tissues, and produces the severe cellulitis and debilitation observed in these animals. We therefore suggest that abscesses and bite wounds in pinnipeds should be subjected to appropriate microbiological investigation to determine if either C. pinnipediorum subspecies is present to help determine the origin of the wounds/abscesses which may help to determine treatments for live animals and possible ultimate causes of death.

Acknowledgements. The Scottish Marine Animal Stranding Scheme receives financial support from the Scottish Government Marine Directorate and the UK Department of Environment, Farming and Rural Affairs (Defra). M.P.D. was funded by the Scottish Government. Three California sea lions at SeaWorld were contributed under SeaWorld Parks and Entertainment technical contribution number 2020-15.

\section{LITERATURE CITED}

Baily JL, Méric G, Bayliss S, Foster G and others (2015) Evidence of land-sea transfer of the zoonotic pathogen Campylobacter to a wildlife marine sentinel species. Mol Ecol 24:208-221

Baily JL, Foster G, Brown D, Davison NJ and others (2016) Salmonella infection in grey seals (Halichoerus grypus), a marine sentinel species: pathogenicity and molecular typing of Salmonella strains compared with human and livestock isolates. Environ Microbiol 18:1078-1087

* Bik EM, Costello EK, Switzer AD, Callahan BJ and others (2016) Marine mammals harbor unique microbiotas shaped by and yet distinct from the sea. Nat Commun 7 : 10516

Brownlow A, Onoufriou A, Bishop J, Davison N, Thompson D (2016) Corkscrew seals: grey seal (Halichoerus grypus) infanticide and cannibalism may indicate the cause of spiral lacerations in seals. PLOS ONE 11:e0156464

Chua K, Gurtler V, Montgomery J, Fraenkel M, Maeall BC, Grayson ML (2007) Campylobacter insulaenigrae causing septicaemia and enteritis. J Med Microbiol 56: 1565-1567

Dierauf LA (1994) Pinniped forensic necropsy and tissue collection guide. NOAA Tech Memo NMFS-OPR-94-3. US Department of Commerce, National Marine Fisheries Service, Silver Spring, MD

Foster G, Holmes B, Steigerwalt AG, Lawson PA and others (2004) Campylobacter insulaenigrae sp. nov., isolated 
from marine mammals. Int J Syst Evol Microbiol 54: 2369-2373

Foster G, Whatmore AM, Dagleish MP, Malnick H and others (2019) Forensic microbiology reveals that Neisseria animaloris infections in harbour porpoises follow traumatic injuries by grey seals. Sci Rep 9:14338

García-Peña FJ, Pérez-Boto D, Jiménez C, San Miguel E and others (2010) Isolation and characterisation of Campylobacter spp. from Antarctic fur seals (Arctocephalus gazella) at Deception Island, Antarctica. Appl Environ Microbiol 76:6013-6016

Gilbert MJ, Miller WG, St Leger J, Chapman MH, Timmerman AJ, Foster G, Wagenaar JA (2017) Campylobacter pinnipediorum sp. nov. subsp. pinnipediorum subsp. nov. \& Campylobacter pinnipediorum sp. nov. subsp. caledonicus subsp. nov., isolated from pinnipeds. Int J Syst Evol Microbiol 67:1961-1968

Gilbert MJ, Zomer AL, Timmerman AJ, Spaninks MP and others (2018) Campylobacter blaseri sp. nov. isolated from common seals (Phoca vitulina). Int J Syst Evol Microbiol 68:1787-1794

* Gilbert MJ, IJsseldijk LL, Rubio-García A, Gröne A and others (2020) After the bite: bacterial transmission from grey seals (Halichoerus grypus) to harbour porpoises (Phocoena phocoena). R Soc Open Sci 7:192079

González M, Paz Villaneuva M, DeBruyne L, Vandamme P, Fernández H (2011) Campylobacter insulaenigrae: first

Editorial responsibility: Stephen Raverty,

Abbotsford, British Columbia, Canada isolation report from South American sea lion (Otaria flavescens, Shaw, 1800). Braz J Microbiol 42:261-265

Leopold MF, Begeman L, van Bleijswijk JDL, IJsseldijk LL, Witte HJ, Gröne A (2015) Exposing the grey seal as a major predator of harbour porpoises. Proc R Soc B 282:20142429

* Miller WG, Yee E, Chapman MH, Smith TPL and others (2014) Comparative genomics of the Campylobacter lari group. Genome Biol Evol 6:3252-3266

* Sheppard SK, Dallas JF, Strachan NJC, MacRae M and others (2009) Campylobacter genotyping to determine the source of human infection. Clin Infect Dis 48:1072-1078

Skirrow MB (1994) Diseases due to Campylobacter, Helicobacter and related bacteria. J Comp Pathol 111:113-149

* Stoddard RA, Miller WG, Foley JE, Lawrence J, Gulland FMD, Conrad PA, Byrne BA (2007) Campylobacter insulaenigrae: isolates from North American elephant seals (Mirounga angustorostris) in California. Appl Environ Microbiol 73:1729-1735

Strachan NJ, Forbes KJ (2010) The growing UK epidemic of campylobacteriosis. Lancet 376:665-667

* Tam CC, Rodriguez LC, Viviani L, Dodds JP and others (2012) Longitudinal study of infectious intestinal disease in the UK (IID2 study): incidence in the community and presenting to general practice. Gut 61:69-77

* Van Neer A, Jensen LF, Siebert U (2015) Grey seal (Halichoerus grypus) predation on harbour seals (Phoca vitulina) on the island of Helgoland, Germany. J Sea Res 97:1-4

Submitted: June 19, 2020; Accepted: September 29, 2020

Proofs received from author(s): November 15, 2020 